\title{
THE RELEVANCE OF CYTOKINE INDICATORS IN THE HEMORRHAGIC TRANSFORMATION DEVELOPMENT OF CEREBRAL INFARCTION RISK MEASURING
}

\author{
T.A. Nikiforova ${ }^{1}$, B.M. Doronin ${ }^{2}$, S.A. Peskov ${ }^{1,2}$
}

${ }^{1}$ VAT City Clinical Hospital No. 1, Novosibirsk, Russia;

${ }^{2}$ Novosibirsk State Medical University, Novosibirsk, Russia

\section{АКТУАЛЬНОСТЬ ПОКАЗАТЕЛЕЙ ЦИТОКИНОВ В РАЗВИТИИ ГЕМОРРАГИЧЕСКОЙ ТРАНСФОРМАЦИИ ПРИ ИЗМЕРЕНИИ РИСКА ЦЕРЕБРАЛЬНОГО ИНФАРКТА}

\author{
Т.А. Никифорова ${ }^{1}$, Б.М. Доронин ${ }^{2}$, С.А. Песков ${ }^{1,2}$ \\ ${ }^{1}$ СПб ГБУЗ «Детская городская клиническая больница № 1», Новосибирск; \\ ${ }^{2}$ ФГБОУ ВО «Новосибирский государственный медицинский университет», Новосибирск
}

The purpose of this research is to study the prognostic role of cytokines in plasma in patients with cerebral infarction while assessing the risk of hemorrhagic transformation.

Materials and methods. Three groups of patients were identified. Group 1: 66 patients with cerebral infarction without hemorrhagic transformation (CI without HT), mean age 63.9 \pm 1.3 years. Group 2: 27 patients with cerebral infarction and with hemorrhagic transformation (CI with HT), mean age was $65.9 \pm 2.5$ years. Group 3: 65 patients with cerebral hemorrhage $(\mathrm{CH})$, average age $-58.8 \pm 1.6$ years. The plasma cytokines concentration measurement (IL-1 $\beta$, TNF- $\alpha$, IL-6, IL-8, IFN- $\gamma$, IL-1Ra, IL-10, IL-4) was performed on the $1^{\text {st }}, 2^{\text {nd }}$ and $10^{\text {th }}$ days after the stroke manifestation. The control group -55 donors cytokines indicators.

Results. In the CI with HT group, compared with the CI without HT group and the $\mathrm{CH}$ group, the lowest levels of IL-1 $\beta$ and TNF- $\alpha$ were detected on the $1^{\text {st }}, 2^{\text {nd }}$ and $10^{\text {th }}$ day since the disease symptoms, and, conversely, the highest IL-1Pa values were revealed on the $1^{\text {st }}$ and $2^{\text {nd }}$ days; IL-4 values - on the $1^{\text {st }}$ and $10^{\text {th }}$ days $(p<0.05)$. The high HT development risk factors on the $1^{\text {st }}$ day of the disease symptoms are IL-6 $\geq 46.6 \mathrm{pg} / \mathrm{ml}$, IL- $8 \geq 14.7 \mathrm{pg} / \mathrm{ml}$, IL- $10 \geq 12.1 \mathrm{pg} / \mathrm{ml}$, IL-4 $\geq 7.6 \mathrm{pg} / \mathrm{ml}$. In contrast, IL- $1 \beta \geq 1.9 \mathrm{pg} / \mathrm{ml}$, TNF- $\alpha \geq 14.4 \mathrm{pg} / \mathrm{ml}$ indicate a low probability of HT development.

Conclusion. Predictors of the CI HT development risk on the 1st day of the disease are plasma cytokines indicators IL-1 $\beta$, TNF- $\alpha$, IL-6, IL-8, IL-10, IL-4.

Keywords: hemorrhagic transformation; cerebral infarction risk; cerebral infarction; cytokines.

Цель исследования - изучить прогностическую значимость цитокинов сыворотки крови больных ишемическим инсультом в рискометрии развития геморрагической трансформации. Maтериалы и методы. Обследованы три группы больных: 1-я группа - 66 больных ишемическим инсультом (ИИ) без геморрагической трансформации (ГТ), средний возраст $-63,9 \pm 1,3$ года; 2-я группа -27 пациентов ИИ с ГТ, средний возраст $-65,9 \pm 2,5$ года; 3-я группа -65 больных геморрагическим инсультом (ГИ), средний возраст $-58,8 \pm 1,6$ года. Определение концентрации цитокинов (ИЛ-1ß, ФНО- $\alpha$, ИЛ-6, ИЛ-8, ИФН- $\gamma$, ИЛ-1Ра, ИЛ-10, ИЛ-4) сыворотки крови проводили в 1-е, 2-е и 10 -е сутки от начала инсульта. Контрольная группа - показатели цитокинов 55 доноров. Резульmamb. В группе ИИ с ГТ сравнении с группами ИИ без ГТ и ГИ выявлено наиболее низкое содержание ИЛ-1 $\beta$ и ФНО- $\alpha$ в 1-е, 2-е и 10-е сутки заболевания и, напротив, наиболее высокие показатели ИЛ-1Ра в 1-е и 2-е сутки и ИЛ-4 в 1-е и 10 -е сутки $(p<0,05)$. Факторами высокого риска развития ГТ в 1 -е сутки ИИ являются показатели ИЛ- $6 \geq 46,6$ пг/мл, ИЛ-8 $\geq 14,7$ пг/мл, ИЛ-10 $\geq 12,1$ пг/мЛ, ИЛ-4 7,6 пг/мл. Напротив, показатели ИЛ-1 $3 \geq 1,9$ пг/мл, ФНО- $\alpha \geq 14,4$ пг/мл свидетельствуют о низкой вероятности ГТ. Заключение. Предикторами риска развития ГТ ИИ в 1-е сутки заболевания являются показатели цитокинов сыворотки крови ИЛ-1 $\beta$, ФНО- $\alpha$, ИЛ-6, ИЛ-8, ИЛ-10, ИЛ-4.

Ключевые слова: геморрагическая трансформация; рискометрия; инсульт; цитокины.

Introduction. In the $21^{\text {st }}$ century, acute cerebrovascular disorders remain one of the most important medical and social problems [1]. Nowadays, systemic thrombolytic therapy (TLT) is one of the most effective cerebral infarction treatments (ESO, 2008; ASA, 2013). However, in the NINDS, ATLANTIS, ECASS I-III, SITS-MOST studies, the use of systemic TLT resulted in 1.7-6.8\% of cases of post-ischemic symptomatic intracranial hemor- rhage, which caused (especially, in the evidence of type 2 parenchymal hematoma) mortality was from 45 to $83 \%$ [2], which explains the importance of researches dedicated to the study of the pathogenesis of hemorrhagic transformation (HT) of the ischemic center and the search for preventive diagnostic methods for assessing the risk of its development.

The most studied causes of HT became the basic reason of contraindications for TLT, officially ap- 
proved by the American Heart Association Stroke Council, 1994. Russian scientists identified risk factors for HT without the use of TLT, the so-called "spontaneous HT": cardioembolic cerebral infarction, increased systolic and diastolic blood pressure on the 1 st and $2^{\text {nd }}$ days after cerebral infarction, a cerebral infarction severity according to the NIHSS $\geq 15$ points, the presence of a permanent form of atrial fibrillation, transient ischemic attacks in the anamnesis, epileptic seizure development in the very beginning of the disease [3].

The search for new predictors of cerebral infarction HT continues. In the pathogenesis of acute cerebrovascular disorders, there is the evidence of the role of the neuroinflammation mechanisms and the ability of neuroglia cells to synthesize inflammatory mediators, particularly, such as cytokines. The imbalance of production and regulation in the cytokine system has a significant impact on the course and outcome of the infarction [4]. However, the problem of the cytokines role in the HT mechanisms remains not completely studied yet.

The purpose of this research is to study the prognostic role of cytokines in plasma in patients with cerebral infarction while assessing the risk of hemorrhagic transformation.

Materials and methods. 158 patients aged 23-91 years who were under treatment on the $1^{\text {st }}$ and $2^{\text {nd }}$ neurological departments within the VAT City Clinical Hospital No. 1 with a diagnosis of acute cerebrovascular disorders were examined. Inclusion criteria were the age 18 years and older; the verified diagnosis of the acute cerebrovascular disease (international disease classification, IDC $=10$ ), admission to the hospital on the $1^{\text {st }}$ day of the development of the stroke; voluntary consent of the patient / his legal representative to take part in the study. Exclusion criteria - the patient's / his legal representative's refusal to participate in the study, the diagnosis of an acute inflammatory, infectious, neurodegenerative, autoimmune disease, the repeated cerebral infarction, traumatic brain injury, acute myocardial infarction, tumor process, including information about surgical operations and taking immunosuppressive drugs at least 12 months before blood sampling. Three groups of patients were identified. Group 1: 66 patients with cerebral infarction without hemorrhagic transformation (CI without HT) - 34 men (52\%) and 32 women $(48 \%)$, mean age $63.9 \pm 1.3$ years. Group 2: 27 patients with cerebral infarction and with hemorrhagic transformation (CI with HT) 17 men (63\%) and 10 women (37\%), mean age was $65.9 \pm 2.5$ years. Group 3: 65 patients with cerebral hemorrhage $(\mathrm{CH})-39$ men $(60 \%)$ and 26 women $(40 \%)$, average age $-58.8 \pm 1.6$ years.

The cytokines concentration measuring (interleukin-1 $\beta$ (IL-1 $\beta$ ), IL-6, IL-8, IL-10, IL-4, tumor necrosis factor- $\alpha$ (TNF- $\alpha)$, interferon- $\gamma$ (IFN- $\gamma$ ), receptor interleukin antagonist-1 (IL-1Ra)) of plasma was performed on the $1^{\text {st }}, 2^{\text {nd }}$ and $10^{\text {th }}$ day after the cerebral infarction manifestation by the method of enzyme-linked immunosorbent assay (ELISA) using test systems "Vector-Best", designed in Novosibirsk. The control group - cytokines indicators of 55 donors, representative by sex and age. On the $10^{\text {th }}$ day, cytokines indicators were determined in 31 patients of the "CI without HT group", as well as in 10 patients of the "CI with HT group", and in 30 patients with cerebral hemorrhage, who have not registered associated inflammatory diseases in the dynamics. The statistical analysis was performed using Microsoft Office Excel 2007, Statistica v. 10.0. For all types of statistical analysis, a critical significance value was determined as $p<0.05$.

Results. The study of plasma cytokines indicators during the acute period of CI with HT revealed that the levels of TNF- $\alpha$, IFN- $\gamma$, IL- 6 , IL-8, IL-1Pa, IL-10, IL-4 exceeded the control values $(p<0.05)$ (Figure 1). However, the level of IL- $1 \beta$ on the $1^{\text {st }}$ and $2^{\text {nd }}$ days in patients with CI with HT was not statistically so much different from the values of the control group $(p>0.05)$.

On the contrary, by the $10^{\text {th }}$ day after the disease manifestation in patients with CI with HT, compared to the control group, a decrease in the content of IL-10 $(p>0.05)$ with increasing IL-1 $\beta$ values was observed along with the persistent hyperproduction of IL-1Pa $(p<0.05)$. This feature was not observed in the groups of patients with $\mathrm{CI}$ without $\mathrm{HT}$ and $\mathrm{CH}$ : the indicators of all the examined plasma cytokines of patients from both these groups statistically exceeded significantly control values.

Comparative analysis of cytokines indicators in patients groups with $\mathrm{CI}$ with $\mathrm{HT}, \mathrm{CH}$ and $\mathrm{CI}$ without HT did not reveal statistically significant differences in the content of pro-inflammatory (TNF- $\alpha$, IFN- $\gamma$, IL-6, IL-8) and anti-inflammatory (IL-10, IL-4) plasma cytokines neither on the $1^{\text {st }}-2^{\text {nd }}$, or the 10 th day after the disease manifestation $(p>0.05)$. However, in patients with CI with HT, a low content of proinflammatory cy-

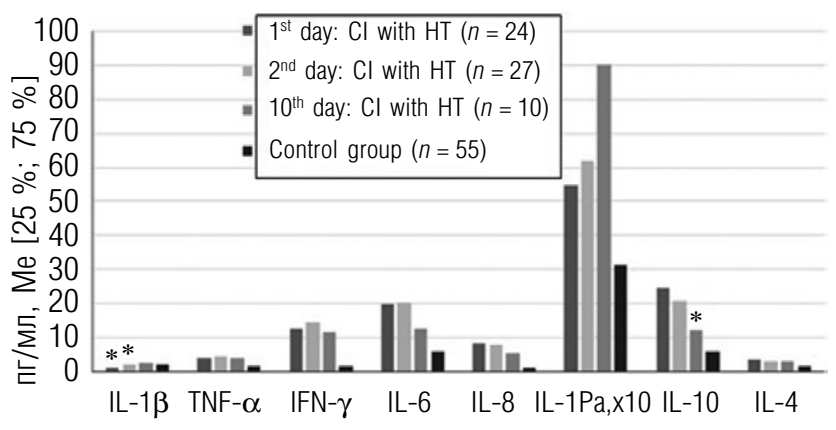

Fig. 1. Plasma cytokines indicators of patients both with cerebral infarction and hemorrhagic transformation and of healthy people. ${ }^{*} p>0.05$ considering the difference between CI with HT and control values 
Plasma cytokines indicators analysis of examined groups

\begin{tabular}{|c|c|c|c|c|c|c|}
\hline \multirow{2}{*}{ Indicator, pg/ml } & \multicolumn{2}{|c|}{$\mathrm{Cl}$ without $\mathrm{HT}$} & \multicolumn{2}{|c|}{ Cl with HT } & \multicolumn{2}{|c|}{$\mathrm{CH}$} \\
\hline & $n$ & $M \pm S . E$. & $n$ & $M \pm S . E$. & $n$ & $M \pm S . E$. \\
\hline IL-1 $\beta \_1^{\text {st }}$ day & 66 & $10.7 \pm 3.2^{*, * *}$ & 24 & $1.6 \pm 0.3^{*}$ & 65 & $3.5 \pm 0.5^{* *}$ \\
\hline TNF- $\alpha \_1^{\text {st }}$ day & 66 & $29.6 \pm 6.3^{*, * *}$ & 24 & $8.0 \pm 2.7^{*}$ & 65 & $13.3 \pm 2.0^{* *}$ \\
\hline IL-1Pa_1 ${ }^{\text {st }}$ day & 65 & $725 \pm 86$ & 23 & $802 \pm 168^{* * *}$ & 65 & $513 \pm 71^{* * *}$ \\
\hline IL-4_1 ${ }^{\text {st }}$ day & 64 & $3.2 \pm 0.2$ & 23 & $4.7 \pm 0.9$ & 64 & $3.7 \pm 0.5$ \\
\hline IL-1 $\beta \_2^{\text {nd }}$ day & 66 & $8.0 \pm 1.4^{*, * *}$ & 27 & $2.1 \pm 0.5^{*}$ & 65 & $4.3 \pm 0.9^{* *}$ \\
\hline TNF- $\alpha \_2^{\text {nd }}$ day & 66 & $26.3 \pm 5.6^{*}$ & 27 & $10.3 \pm 3.3^{*}$ & 65 & $16.5 \pm 2.9$ \\
\hline IL-1Pa_2nd day & 66 & $819 \pm 93$ & 27 & $892 \pm 142$ & 65 & $720 \pm 98$ \\
\hline IL-4_2 $2^{\text {nd }}$ day & 66 & $3.2 \pm 0.2^{*}$ & 27 & $4.1 \pm 0.6^{*}$ & 65 & $3.7 \pm 0.3$ \\
\hline IL-1 $\beta_{-} 10^{\text {th }}$ day & 31 & $9.3 \pm 2.5^{*, * *}$ & 10 & $3.2 \pm 1.1^{*}$ & 30 & $4.8 \pm 1.0^{* *}$ \\
\hline TNF- $\alpha \_10^{\text {th }}$ day & 31 & $32.0 \pm 9.9^{*, * *}$ & 10 & $8.3 \pm 3.2^{*}$ & 30 & $11.8 \pm 2.6^{* *}$ \\
\hline IL-1Pa_10 ${ }^{\text {th }}$ day & 31 & $836 \pm 131$ & 10 & $1009 \pm 266$ & 30 & $824 \pm 165$ \\
\hline IL-4_10 ${ }^{\text {th }}$ day & 31 & $3.5 \pm 0.4^{*}$ & 10 & $5.4 \pm 1.9^{*, * * *}$ & 30 & $3.5 \pm 0.3^{* * *}$ \\
\hline
\end{tabular}

Note. The table presents the results of the ANOVA and Newman-Keuls test; $* p<0.05$ for CI without HT and CI with $\mathrm{HT} ;{ }^{* *} p<0.05$ for CI without $\mathrm{HT}$ and $\mathrm{CH} ;{ }^{* * *} p<0.05$ for CI with HT and $\mathrm{CH}$.

tokines - IL- $1 \beta$ and TNF- $\alpha$ - was revealed on the $1^{\text {st }}, 2^{\text {nd }}$ and $10^{\text {th }}$ days of the disease, and, on the contrary, high rates of anti-inflammatory cytokines $-\mathrm{IL}-1 \mathrm{~Pa}-$ on the $1^{\text {st }}$ and $2^{\text {nd }}$ days, and IL-4 - on the $1^{\text {st }}$ and the $10^{\text {th }}$ days (table 1 ).

Predictors of HT development were established in patients with cerebral infarction on the 1st day of the disease: IL- $6 \geq 46.6 \mathrm{pg} / \mathrm{ml}$ (OR $4.1 ; 95 \%$ CL 1.2-13.9), IL-8 $\geq 14.7 \mathrm{pg} / \mathrm{ml}$ (OR 6.0; 95\% CL $1.7-21.2$ ), IL- $10 \geq 12.1 \mathrm{pg} / \mathrm{ml}$ (OR $3.2 ; 95 \%$ CL 1.03-9.8), IL-4 $\geq 7.6 \mathrm{pg} / \mathrm{ml}$ (OR 22.2; 95\% CL 2.4-204.1), IL- $1 \beta \geq 1.9 \mathrm{pg} / \mathrm{ml}$ (OR 0.2; 95\% CL $0.1-0,6)$, TNF- $\alpha \geq 14.4 \mathrm{pg} / \mathrm{ml}$ (OR $0.2 ; 95 \% \mathrm{CL}$ $0.1-0.8)$.

Discussion. Thus, the peculiarity of the CI with HT course, in comparison with other types of infarction, is the cytokine imbalance, expressed in the beginning of the disease as deficiency of pro-inflammatory cytokines (IL- $1 \beta$ and TNF- $\alpha$ ) and anti-inflammatory activity cytokines hyperproduction (IL-1Pa, IL-10 and IL-4), which is an example of the adaptation breakdown with the development of an acute immunodeficiency state in response to ischemia [5], and, as a result, a shift in the Th1/Th2 balance towards the predominance of the Th2-cytokine response [6, 7]. Two main mechanisms for the implementation of post-stroke immunosuppression are described: hypothalamic pituitary adrenal cystic system activation with adrenal synthesis of glucocorticoids (GCC) and sympatho adrenal system stimulation with the release of catecholamine (CA), with the result that the GCU and the CA hinder the production of pro-inflammatory cytokines, which release catecholamines (CA), as a result, GCC and $\mathrm{CA}$ inhibit the production of proinflammatory cytokines IL- $1 \beta, \mathrm{TNF}-\alpha, \mathrm{IFN}-\gamma$. In addition, CAs are capable of mediating IL-10 inhibiting the production of IL- $1 \beta$ and TNF- $\alpha$ [6]. As a result, the functional connections of the cytokine network deviate from deterministic algorithms and become pathological. The cytokine imbalance detected in patients with CI with HT corresponds to the stage of adaptation mechanisms dysfunction, when the "immune paralysis" development and a compensatory anti-inflammatory response ("compensatory anti-inflammatory response syndrome") occurs, with the release of anti-inflammatory cytokines IL-4 and IL-10 into the systemic circulation, which inhibit synthesis with the proinflammatory phase mediators macrophages (IL-1, TNF- $\alpha$ and IL-6) [8].

It has been proven that plasma cytokines indicators on the $1^{\text {st }}$ day 1 of the CI are predictors of the HT developing risk.

Conclusion. The results of the study prove the prognostic significance of plasma cytokines (IL-1 $\beta$, TNF- $\alpha$, IL-6, IL-8, IL-10, IL-4) in assessing the risk of HT development on the $1^{\text {st }}$ day since the cerebral infarction manifestation. The high HT development risk factors on the $1^{\text {st }}$ day after the CI are the following values: IL- $6 \geq 46.6 \mathrm{pg} / \mathrm{ml}, \mathrm{IL}-8 \geq 14.7 \mathrm{pg} / \mathrm{ml}$, IL- $10 \geq 12.1 \mathrm{pg} / \mathrm{ml}, \mathrm{IL}-4 \geq 7.6 \mathrm{pg} / \mathrm{ml}$. In contrast, the values of IL- $1 \beta \geq 1.9 \mathrm{pg} / \mathrm{ml}, \mathrm{TNF}-\alpha \geq 14.4 \mathrm{pg} / \mathrm{ml}$ indicate a low HT development probability. 


\section{References}

1. Stakhovskaya LV, et al. Epidemiology of stroke in Russia according to the results of the territorial population register (2009-2010). Journal of Neurology and Psychiatry. Ss Korsakov. 2013;(5):5-10.

2. Batishcheva EI, Kuznetsov AN. Hemorrhagic transformation of cerebral infarction: clinical and radiological options, risk factors, prognostic value. Neurological Journal. 2008;13(5):29-34.

3. Batishcheva EI. Hemorrhagic transformation of cerebral infarction: clinical and tomographic structure, risk factors, the impact on early outcome: author. dis. ... Dr. med Sciences: 14.00.13 / Batisheva Elena Ivanovna. Moscow; 2009. 50 p.

4. Amantea D., et al. Post-ischemic brain damage: pathophysiology and role of inflammatory mediators. FEBS J. 2009;276(1):13-26.

5. Prass K, et al. Stroke-induced immunodeficiency promotes spontaneous bacterial infections and is mediated by sympathetic activation reversal by poststroke T helper cell type 1-like immunostimulation. J Exp Med. 2003;198(5):725-736.

6. Galea J, Brough D. The role of inflammation and interleukin-1 in acute cerebrovascular disease. $J$ Inflamm Res. 2013;6:121-128.

7. Offner H, Vandenbark AA, Hurn PD. Effect of experimental stroke on peripheral immunity: CNS ischemia induces profound immunosuppression. Neuroscience. 2009;158(3):1098-1111.

8. Makarova VI, Makarov AI. The role of cytokines in the inflammatory reaction implementation. Human Ecology. 2008;(5):31-35. 